\title{
Postsecular spirituality, engaged hermeneutics, AND Charles TAYLOR'S NOTION OF HYPERGOODS
}

Author:

Andries G. van Aarde ${ }^{1}$

\section{Affiliation: \\ ${ }^{1}$ Faculty of Theology, \\ University of Pretoria, \\ South Africa}

\section{Correspondence to:}

Andries G. Van Aarde

e-mail:

andries.vanaarde@up.ac.za

\section{Postal address:}

Faculty of Theology,

University of Pretoria,

South Africa

\section{Keywords:}

religious orientation and spirituality; morality and the ethics of justice; Charles Taylor's theo-philosophy; secularisation; neoorthodoxy

\section{Dates:}

Received: 18 Apr. 2009

Accepted: 14 June 2009

Published: 07 Aug. 2009

How to cite this article: Van Aarde, A.G., 2009,

'Postsecular spirituality, engaged hermeneutics, and Charles Taylor's notion of hypergoods', HTS Teologiese Studies/Theological Studies 65(1), Art. \#166, 8 pages. DOI: $10.4102 /$ hts.v65i1.166

\section{Note:}

This article was originally presented as a paper at the Conference of the Spirituality Association of South Africa (SPIRASA), 16-17 April 2009, Santa Sophia Centre, Waterkloof, Pretoria. Andries van Aarde is Honorary Professor in the Faculty of Theology, University of Pretoria, South Africa.

This article is available at: http://www.hts.org.za

(C) 2009. The Authors. Licensee: OpenJournals Publishing. This work is licensed under the Creative Commons Attribution License.

\section{ABSTRACT}

This essay sets out to argue that postsecular spirituality is about the quest for hypergoods within today's mass populist- and consumerist-oriented world. It shows that people who consider themselves to be spiritual not only have many values in their lives, but rank some values higher than others, with some being ranked as being of supreme importance, the so-called hypergoods. Such ethics has an interpersonal character, and in Christian circles this reopens the issue of biblical hermeneutics, especially the phenomenon of conflicting interpretations. Against the background of the various options of being religious in the secular age, the essay focuses on Charles Taylor's view of the discovery of spirituality in a posttheistic world and his emphasis on the love of God and the ethics of justice as hypergoods.

Vocatus atque non vocatus deus aderit ('Invoked or not invoked, God will be present') (Carl Gustav Jung, in Selesnick 1966:63)

\section{INTRODUCTION: \\ DISCOVERING SPIRITUALITY IN A POSTTHEISTIC WORLD}

In his book, Ethics in the global village: Moral insights for the post 9-11 USA, Hill (2008) refers to the words of the pastoral counsellor Howard Clinebell (1984:138), who stated that our age is marked by 'an epidemic of moral confusion and value distortion'. According to Hill (2008:16), we 'are like children torn by a divorce, trying to decide which parent to live with - the relativist or the dogmatist'. However, 'to frame our moral epidemic in this polar fashion is to ignore broad spectrums of actual moral experience' (Hill 2008:17). Against the background of this 'epidemic' and the possible 'broad spectrums', this essay emphasises the fullness of being spiritual, even in the secular age.

However, to be spiritual and to do theology in our present-day context does not imply the denial of being rational too. A sacrificium intellectus is not a prerequisite for being spiritual or religious. A change of paradigm, however, also does not mean business as usual. Fifteen years ago, in an appeal for 'engaged hermeneutics' with regard to responsible morality in the light of the postmodern paradigm shift, I cited Herbert Butterfield's (1975:1) words that what we need is 'putting on a different kind of thinking cap' (Van Aarde 1994:584-585). On the basis of two citations, from Butterfield's (1975) The origins of modern science: 1300-1800 and Kuhn's ([1957] 1979) The Copernican revolution respectively, Kopfensteiner puts it as follows in an article entitled 'Historical epistemology and moral progress':

A shift of paradigm will result in "handling the same bundle of data as before, but placing them in a new system of relations with one another by giving them a different framework, all of which virtually means putting on a different kind of thinking cap". A scientific revolution has a dual nature; it is "at once ancient and modern, conservative and radical". To some practitioners the new paradigm will be the point of departure for previously unanticipated scientific activity; to others, however, the new paradigm will seem curiously akin to its predecessors.... Hence, each evolutionary niche of development understands the world differently, but never independently of its predecessors...The epistemological discussion within philosophy and history of science has shown that ...(t)he reciprocity of tradition and the emancipation accounts for moral progress. At each evolutionary niche, new possibilities of being-in-the-world are opened up to human freedom. This is the meaning of a shift of paradigm in a moral context, and its possibility rests on a historical [i.e. a social constructionist - A.G. $v$ A. $]^{1}$ rather than essentialistic understanding of the moral law.

(Kopfenstein 1992:47, 57)

Secularity represents such a 'shift of paradigm in a moral context' and has brought about a change in traditional Christendom. Charles Taylor, Emeritus Professor of Philosophy and Political Science at McGill University in Montreal, Canada, sees a link between classical theism (or even pantheism), practiced by Augustine in the fourth century for example, and the movement away from theism, brought about by Jean Jacques Rousseau. Taylor describes the continuity in this paradigm shift, which happened despite Rousseau's notion of self-determining freedom, as follows:

To see what is new in this, we have to see the analogy to earlier moral views, where being in touch with some source - God, say, or the Idea of the Good - was considered essential to full being. Only now the source we have to connect with is deep in us. This is part of the massive subjective turn to modern culture, a new form of inwardness, in which we come to think of ourselves as beings with inner depths. At first, this idea that the

1. Yolanda Dreyer (2006:157), with reference to Berger and Luckmann's book (1967), The social construction of reality: A treatise in the sociology of knowledge, explains 'social constructionism' - over against the notion of immutability in the concept 'essentialism' - as sociology of knowloge, explains 'social constructionism' - over aganst the notion of inmutability in the concept 'essentialism' - as follows. 'Berger \& Luckin (1967:4) refer to the Seinsgebundenheit (the existential determination") of human knowledge. According to the sociology of knowledge, reality itself is a social construct, a product of socially conditioned observation. According to this view, authors of texts - present or past - give creative expression to reality. These expressions are produced within the constraints of history and are shaped by the personal and social experiences of the authors, who share a framework of credibility with their audiences. No communication or social interaction can take place outside of such shared social and cultural frameworks. Beliefs expressed in language are credible within a specific frame of reference. Within this framework concepts are shared and views that contribute to meaning making can be appropriated. Communication happens within a framework of shared concepts and a common context. In this way truth claims can gain credibility and convictions acquire power. Also within this framework unacceptable points of view and harmful interactions will be exposed.' 
source is within doesn't exclude our being related to God or the Ideas; it can be considered our proper way to them.

(Taylor 1991:126)

Taylor (1991) refers to the aptitude of this new form - which Richard Grigg (1985), with reference to Paul Tillich's theo-philosophy, called a 'posttheistic system' - as the 'ethics of authenticity'. Being spiritual as a Christian in the secular age and being authentic in the above sense of the word require a commitment to what I refer to as 'engaged hermeneutics'.

My understanding of the concept of 'authenticity' is influenced philosophically, most particularly by Martin Heidegger's interpretation of the German word eigentlich. In the introduction to his commentary on Heidegger, Michael Inwood (2000:26) explains it as follows: 'To be authentic is to be true to one's own self, to be one's own person, to do one's own thing.' However, such autonomy does not imply 'exclusive humanism', which was, as we shall see, implemented when modern rationalism reached its peak.

In the course of presenting such 'ethics of authenticity' in this essay, two concepts, namely 'posttheism' and 'engaged hermeneutics', ought to be clarified at the outset. It seems reasonable that posttheism (see discussion of use of hyphenated and unhyphenated form later) presupposes a departure from theism. However, the critical part of the definition of 'posttheism' has to do with the prefix 'post-', which signifies two different meanings in one compound word. The same applies to a discussion within the field of postcolonial theory (Ashcroft, Griffiths \& Tiffin 1989:1-4; Moore 2000:182-188; Young 1996:6768; 2001:1-10) and that of 'postmodernity' (e.g. Schrag 1997:6974, 129; Van Huyssteen 1999:137-139).

According to Moore (2000:182), a conception of 'post (-)' can be viewed as 'naïve, inadequate, or utopian'. Young (1996:6768; cf. Donaldson 1998:5) points out that the prefix 'post-' is symptomatic of putting 'oneself on the outside' by assuming a 'postness' and a 'newness', to such an extent that one gets outside oneself by stepping outside one's 'own skin'.

If the two words 'post' and 'theism' are compounded to form one meaning, then it is important to understand what 'post(-)' brings anew to 'theism'. It certainly does not mean that the belief patterns that marked theism are things of the past. The 'post' in 'posttheism' is not simply a historical event in which one can move from 'theism' to 'post'-religiosity in the sense of a total disenchantment, or to 'strong' atheism, which, in an age of reason, denies any existence of gods (see Philipse [2004] who claims theism to be an 'epistemological tragedy'). Furthermore, the 'post' in 'posttheism' does not imply a present-day 'logical positivism' that upholds the traditional proposition that 'God exists' as a 'truth of a conceptual necessity' (see Swinburne [1977] 1993:272-278; Sobel 2004). It is nonsense to assume a logical continuity between 'theism' and 'atheism', similar to the linear continuation between modernism and post-modernism or the continuation between colonialism and post-colonialism, and analogous to the shift from a pre-Copernican mythological worldview to a post-Copernican scientific worldview.

The term 'posttheism', without the hyphen, is preferred, because it is less 'suggestive of (imagined) chronological or ideological supersession' (Moore 2000:182, with regard to 'postcolonialism'). Theism as a concept and, as a practice, is still active in a new form today. This new form is 'neo-orthodoxy'. Many different conceptualisations of the existence and nature of God still prevail today. Theism, pantheism, panentheism, deism, fideism, monotheism, polytheism and henotheism are all views that affirm the existence of a transcendent God and affirm that God is involved in creation. Henotheism, like agnosticism, is a polytheistic view according to which there are many gods, but in the case of henotheism special respect is paid to one of them, while agnosticism refuses any particular homage to a specific godhead. It seems that some atheists are also tolerant towards the conviction of believers that God exists. However, 'strong atheism' (referred to by Philipse [2008:179] as 'disjunctive atheism') advocates the absence of authenticity when adhering to whatsoever a theistic belief that ascribes attributes, such as omnipotence, omniscience, immutability (the quality of being unchangeable) and impassibility (incapable of suffering), to a god.

The unhyphenated compound word, 'posttheism', refers to a postmodern way of thinking that evolved as a critique on certain aspects of theism. It supposes a selective departure, but not a total break. It still affirms the existence of a transcendental God, without endorsing the old and mythical view that the world consists of three levels, namely heaven, earth and the underworld. If people were still to subscribe to this old worldview, it would amount to an instance of sacrificium intellectus.

Being spiritual within a posttheistic paradigm requires of one to ask the critical question on what is meant by speaking in a metaphorical manner about the Transcendence's actions with humankind. Yet, no one, including the writers of the Christian Bible, can speak about God in any manner other than by means of 'objectifying language'. Despite that, a posttheistic disposition acknowledges a dialectical manner of speaking metaphorically about God, while it does not want to objectify and humanise, or reify, God. God-talk, which manifests as an objectifying speaking about God's actions, does not necessarily imply that God becomes an object that interacts with people in ways similar to those in which one human being encounters another human being. Neither does it intend to imply that any speaking about God's actions could be possible without an analogous manner of speaking. God's actions cannot be proven objectively. These actions can only be experienced and seen in the effects they have on human beings' existential involvement in them.

Posttheism acknowledges that no worldview is final, and neither is the biblical manner of speaking therefore final. Within the Christian faith community, engaged hermeneutics - through the meeting with Jesus, or with the 'word' Jesus proclaimed, or the 'word' which proclaims Jesus' message - aims to establish the important insight that faith does not uphold propositions as truth but presumes a living, existential relationship with God. Even though Christians are still part of history in this saeculum, they already become new human beings the very moment they make an affirmative decision about faith. Engaged hermeneutics pertains to the interpretation of the Scriptures in such a way that they can be understood as addressing kerygma. Such an interpretation is not devoid of scientific means, because it critically and with suspicion questions the intention and reception of Scriptures.

Engaged hermeneutics thus places the biblical text in a new light and poses new challenges to faith. It also implies that faith is not putting propositions forward as truth, but rather as a living existential relationship with God in the here and now of a believer's life. Discovering spirituality in a posttheistic world means engagement with God and fellow human beings in a world that takes both science and faith seriously. This, however, would not have been possible without the change that secularisation had brought about and the perseverance of faith in the transcendental God. This, in short, is what postsecular spirituality is all about: the quest for hypergoods in today's mass populist and consumerist-oriented world (see Melton 2001).

\section{POSTSECULAR SPIRITUALITY}

It therefore does not come as a surprise that what theologians consider to be the most prestigious award in our present, socalled secularised world, which is ruled by the rise and fall of the free market economy, is not Oslo's Nobel Prize, but the prize of the John Templeton Foundation, awarded for 'progress toward research or discoveries about spiritual realities' (John 
Templeton Foundation 2009) - although this is ironical too, because of the postmodernist critique against of present-day consumerist culture. In 2008, this award was worth $\$ 1.6$ million and was made by the Duke of Edinburgh during a ceremony at Buckingham Palace on 7 May 2008. Previous laureates include figures such as the Russian novelist Alexander Solzhenitsyn, in 1983, for his 'struggle for open expression', a 'living symbol of freedom of thought and conscience'; Nobel Peace Prize winner Mother Teresa, in 1973, for 'her extraordinary efforts to help the homeless and neglected children of Calcutta'; and Dr Billy Graham, in 1982, the evangelical theologian, in 1982, who for being the one who 'invigorated an entire generation with a simple, yet poignant message of salvation' when he 'took his message of Christianity into the electronic world of radio and television.

Professor Michael (Michał) Heller, a Polish cosmologist, philosopher and Catholic priest, was the 2008 winner for 'linking maths ... to God'. In an interview which followed the announcement that he was that year's winner, Heller explained his affinity for the two fields, science and religion, as follows: 'I always wanted to do the most important revolution things, and what can be more important than science and religion? Science gives us knowledge, and religion gives us meaning. Both are prerequisites of the decent existence' (Goodman 2008).

Heller's thinking is in line with that of Charles Taylor, the Templeton Prize winner in 2007. According to Taylor, a 'divorce' between religion and natural science has a damaging effect on both. Yet, it is 'equally true that the culture of the humanities and social sciences has often been surprisingly blind and deaf to the spiritual.'

Secularisation is the consequence of human beings now being able to choose freely whether they want to accept the authority of a transcendent power or not. Our life today consists of repressive reactions through so-called perfunctory passivity, for example by switching off television news bulletins, or through opinionated engagement with our everydayness. Nonchalance and passionate activism are both moral expressions of a freedom of choice on how to react to secularisation. The latter resulted from several types of revolutions since the 15th century: the epistemological revolution, which differentiated between knowledge of the metaphysical world and knowledge of the physical world (triggered by Immanuel Kant [1724-1804]; the two industrial revolutions of 1760 and 1830 respectively; the two political revolutions, the first in France (1789-1799), as the conclusion of ecclesial hegemonies, and the second in North America (1799-1783), as the commencement of bills for individual human rights and the constitutional parting of state and church; the cultural revolutions brought about by the Renaissance (the 15th century's revitalisation of neoclassical art and literature), the Baroque (the emphasis from the 17th to 18th century on flexibility and motion, contra formalistic classicism), and Romanticism (the 19th century's positive reception of story versus history).

Theologies inspired by secularisation are multi-faceted. At the one pole is agnosticism, which is actually a form of 'weak atheism' (see Philipse 2008:179) or even 'modern polytheism' insofar as it does not deny the reality that, for many people, gods do exist, although the agnostic refuses to acknowledge a commitment to religiosity as such. Deism, the belief that God created and that creation takes its own course independently of any divine intervention, is at the opposite pole.

Other secularised theologies have developed between the two poles of deism and agnosticism. On the negative side there is 'strong atheism', a conviction that actively campaigns for the belief in the non-existence of gods, pantheism, which advocates the view that God is equal to the sum total of that which exists, and panentheism, according to which God cannot be equated to that which exists, but that God exists in something that is (see Clayton 2003).
Despite all the variables among secularised theologies, they all share a hostility towards the premodern transcendental theistic belief that God created the world, intervenes in creation and interferes in the fate of creatures, either at God's own initiative, or sometimes on request through prayer; at other times again as a response to human beings' sacrifices or martyred suicide, or martyred death; or in response to peoples' worship and sacramental participation. Besides such an anti-theistic inclination, secularised theologies also contra-act to modern scholasticism and/or neo-orthodoxy. In the secular age, a revitalisation of orthodoxy manifests itself in ideas that God should be worshipped by means of strict adherence to both dogmatic propositional tenets and ecclesialordained liturgical practices, academic-oriented homilies from canonised Scriptures, and the celebration of divinely legitimated sacraments.

Neo-orthodoxy is a Scripture-based ideology in terms of which the Holy Scripture is considered to be normative, although by means of double and selective standards. For example, the Genesis narrative that the world was created in a time span of six days is not interpreted literally; yet biblical references to Jesus Christ's virginal conception and that he was bodily raised from death and ascended into heaven are understood literally as being empirically real. Similar narrations about Heracles or Augustus are regarded as mythical fictions (see, among others, Miller 2003; Scott 2008).

The third feature shared by secularised theologies is that they all reject fideism, which is a 'belief in belief', be that a belief in doctrine or in the church as such (e.g. confessionalism or ecclesialism as a result of views such as the inerrancy of ecclesial creeds or ecclesial canons and office-bearers). Ironically, while neo-orthodox theism is part of the process of modern secularisation, modernistic neo-orthodoxy should be seen as a reaction to secularised liberal theology.

I therefore cannot endorse the appeal to enhance the renewal of 'reformed and evangelical orthodoxy' - such as recently proposed by $\operatorname{Vos}^{2}(2008: 33-35)$ for the secularised Netherlands. However, an enhancement of neo-orthodoxy, even though disguised in seemingly acceptable reformational and/or evangelical vocabulary, would in our time mean regression and an escape from the challenges of postsecular realities. One of these realities is that our present-day context has moved away from what Taylor calls the 'Second Confessional Age' towards the 'Age of Authenticity'. The 'first' confessionalist outlook originated as a product of the sixteenth-century Reformation. The 'second' is the result of a similar situation in which 'churches managed to organize so much of their members' lives, and hence became the focus of often intense loyalty, a sentiment akin to nationalism' (Taylor 2007:471-472). According to Taylor (2007:472), this 'second' confessionalism functioned powerfully and these 'powerful forms of faith wove four strands together in this age: spirituality, discipline, political identity, and an image of civilization order'. These powerful forms of faith 'had become a mass phenomenon' and resulted in 'tightly organized churches, often suspicious of outsiders, with their strongly puritanical codes, their inherent links of whatever sort, to political identities, and their claims to ground civilizational order'. However, it is these 'codes' in particular which 'were perfectly set up for a precipitate fall in the next age which was beginning to dawn at mid-century' (Taylor 2007:472-474).

In his book, Liberal theology: A radical vision, Hodgson (2007:2) endorses the practical theologian from Manchester, Elaine Graham, who wrote: 'The complexities of our situation are where liberal theology begins its work.' Graham identifies some

2.Dr A. Vos teaches systematic theology at the Protestant Theological University in Utrecht (the Netherlands), and is also Professor in Historical Theology at the Evangelische-Theologische Faculteit in Leuven, Belgium. 
qualities of the postmodern condition that might be of value: its fluidity, its pluralism and questioning of authority, its resistance to exclusivism and its openness to religious sensibilities characteristic of the postmodern return of the sacred.

(Graham 2002:138)

Hodgson, affirming what Graham maintains, advocates a respite from secular humanism by offering 'some critical space for religion'. What it requires is courage to address some basic questions:

What does it mean to be human? What kind of a society do we want? And most importantly, What do we worship - gods and idols such as the state, the market, self-interest, progress? Or a God who radically transcends such idols but is also radically immanent in the world as the generative power of freedom?

(Hodgson 2007:2)

\section{POSTSECULAR AUTHENTICITY}

For a long time Taylor (1989) has been objecting to what many social scientists take for granted, namely that the rational movement that began during the Enlightenment renders notions such as morality and spirituality as simply old-fashioned anachronisms in the age of reason. Such a narrow, reductive approach wrongly denies the full account of how and why humans in our postsecular world strive for meaning - also by religious means, albeit in a populist fundamentalist, a culturalcritical or a pentecostal-charismatic foundational mode. The contexts in which these religious means are mushrooming are to be found both within institutional religion and at grassroots level, where there is not necessarily an attachment to ecclesial institutions (cf. Taussig 2006; 2008:149-160). In his A secular age, Taylor $(2007: 226,270,293,437)$ formulates it as follows:

The new natural science did indeed threaten some of the outlying forms which had become intricated with religion, e.g., the Ptolemaic system, and the scholastic method; it did, of course, hasten the disenchantment of the world, helping to split spirit from matter; more seriously, its conception of exceptionless natural law would later raise questions about the possibility of miracles. But this by itself can't explain the turning from devotion and religious experience to an external moralism...Deism can be seen as a halfway house on the road to contemporary atheism...It really reflects a major shift in our background understanding of the human epistemic predicament... a change in horizon which profoundly alters what it means to reason about God, or "religion"...Religious beliefs now exist in a field where there is also a wide range of other spiritual options. But the interesting story is not simply one of decline, but also of a new placement of the sacred or spiritual in relation to individual and social life. This new placement is now the occasion for the recomposition of spiritual life in new forms, and for new ways of existing both in and out of relation to God.

(Taylor 2007:226, 270, 293, 437)

In his book, Grassroots spirituality: What it is, why it is here, where it is going, Forman (2004:4; cf. Leaves 2006:47) describes the breeding ground or mould in which grassroots spirituality is flourishing as

mostly on the margins of mainstream, popular culture and traditional church hierarchies... [not] growing...in science labs, parish naves or university classrooms, but rather in living rooms, church basements, yoga centers, nature walks, meditation rooms and coffee shops all over the nation and the world. It is at heart populist, devoid of leadership or overarching organization.

(Forman 2004:4)

Whether this type of spirituality can still be called religion remains an open question ( $c f$. Taylor 2007:507-508). It seems that, almost at the end of the consummation of the process of secularisation and the destruction of ecclesial hierarchy, i.e. priestly rule (= hierarches), critical philosophers consider the necessity that secularisation still needs to pay its last levy - and that is to organise the funeral of institutional religion at long last. It is in this regard that one of the last living exponents of the neo-Marxist 'Frankfurt School', the German philosopher
Jürgen Habermas, played a significant role (Habermas 1981:314; cf. Browning \& Schüssler Fiorenza 1992).

According to Adams (2006:198), Habermas claims that presentday grassroots spirituality 'strips religious practices of their religiousness'. According to this view, religious traditions lost their operational basis because of the 'collapse of metaphysics [that] caused theologians to assimilate to the atheism of university life, and thus betray their tradition' (Habermas 2002:75-76). However, not even Jacques Derrida, the doyen of postmodern deconstructionism, agrees with such scepticism. ${ }^{3}$ Derrida is of the opinion that, of the various religions existing in the world, Christianity is perhaps the one that could transform itself. The process of globalisation began with 'Roman Christianisation' in the Constantine period from the 4 th century onwards, and Christianity has proved its capability to face 'unpredictable transformations'. According to Derrida (in Caputo, Hart \& Sherwood 2005:33), even if the 'deconstruction of Christianity' develops, the roots of the Christian religion could indeed become unrecognisable and 'yet, nevertheless, we will still be able to say that this is Christianity'.

For Paul Ricoeur ([1989] 1995:306), spirituality that is nurtured by the Jesus narrative can become an agency of hope, also for the church as institute (cf. Drewery, Winslade \& Monk 2000). In Pastoral praxeology, hermeneutics, and identity, Ricoeur refers to it as follows:

It is a problem of identity. It seems to me that this is also a problem for those concerned with pastoral ministry inasmuch as there is always the problem of the 'who': Who is the actor? Who intervenes? One intervenes in relation to whom?... It is in such reflection that the word 'return' takes on meaning, [such] as when I speak of returning to myself, that is, of a return to what I am doing, but also to myself, to the self.

(Ricoeur 1995:306)

This journey of such a 'self' implies that the 'self' as a 'spiritual being' has arrived at a 'second naiveté' (see Wallace [1990] 1995). A second naiveté assumes religio. In the first naiveté, religare was understood in accordance with its meaning of 'binding' or 'keeping in protective custody' (Simpson 1966:511). In this sense of the term, postsecular spirituality would mean the 'end of religion'. According to Ricoeur's sense of the word, religare means to return. This 'return' implies a 'binding' to something that goes back in time. Reliving it again today, as if for the first time, implies a deconstruction, a re-telling in order to both reformulate and retain. This is the 'second naiveté' This returning completes the circle. But completing the circle does not mean returning to the old beginning. It is a process of suspicion that departs from the unacceptable and gives birth to new meaning. Such a 'hermeneutical circle' (Ricoeur 1995:186) of suspicion presupposes a return by means of remembering (in philosophical terms, mimesis; Ricoeur 1984-85) the important narratives of the biblical and ecclesiastical past, especially those of Jesus and of the church's proclamation of his kingdommessage.

This process of returning to the past consists of three steps, all happening simultaneously: prefiguration, configuration, and refiguration (Kearny 2001; 2004). The first implies the rational, critical, suspicious encountering of past faith experiences; in the second, 'I am involved in the encounter', not in a clinical, rational and objective way, but in a critical, rational, consciously suspicious way. The third tells the story of the birth of a new self - the interpretative process has changed me. The hermeneutist Pambrun explains it as follows:

In this sense, the configuration of the narrative becomes a cognitive and existential operation in my refiguring of existence. The present, that is my life, becomes the place where my relationship to the future as hope and my relationship to the past as possibilities

3.In all fairness, Habermas himself changed his mind in the light of the important role institutional religion can play in the present-day combatting of cultural consumerism (see his dialogue with Joseph Ratzinger, the present-day Pope Benedict XV, in 2005 (Habermas \& Ratzinger 2005) 
intersect, namely where the "unused potentialities of the past" are effected on behalf of others.

(Pambrun 2001:296)

So many different options are available to people belonging to our globalising, postsecular mass-consumerist culture. During the bygone ages, prior to the Judeo-Christian option (in its great variety), the options were mainly polytheism or monotheism. Later on, in the Christian West, it became a choice between God and Satan, and then, even later, between different sets of theological dogmatic systems, religious traditions and denominations within a tradition.

Before 1500, people were socialised into 'how things are and should be'. Before the new millennium, 'exclusivist humanism' was the main influence (Taylor 2007:19-21, 26-28, 41, 88, 98-99, $130,134,221,233-234,242-269,636-642,656,768-769)$. Today a much greater variety is available.

As far as the Protestant Christian tradition is concerned, one can say that 'theology', broadly seen, has to do with an ecclesial reflection on the Word of God (as 'revelation') and with the canons of the church (as deduced from the Bible). However, mainline churches do not have the exclusive rights to doing theology. Theology exists in mainline churches as well as in what was previously called 'sects'. While some pentecostal-charismatic groups claim not to be prescribed to by traditional confessions, but to be guided by the Holy Spirit, they too have internalised the central tenets of orthodoxy. This socialisation can also be seen among 'public theologians' such as film directors, poets and novelists. For centuries, people embedded in the Westernised first-continental world have been perpetuating traditional theism, supported by orthodox doctrinal fideism. I am therefore sceptical about the typical distinction that is being made between mainline churches and charismatic churches, as if the two groups operated according to two different 'theologies'.

\section{HYPERGOODS}

It becomes clear that spirituality manifests itself according to a specific paradigm, which represents a kind of default mode to which religious people involuntarily turn until such time as this default mode changes. In his book, A secular age, Taylor argues that the most significant change in the default mode took place over a period of 500 years between 1500 and 2000 CE (Taylor 2007:13). The era before 1500 constituted the mythological premodern era, and that after 1500 the modern secularised era. We have seen that Taylor (2007:27) describes the extremity of the modern era as 'exclusive humanism'. In contrast to mythological theism, people in the secularised, modern world can choose to be religious or not, without the pressure of some external influence or the fear of external retribution.

Anyone who considers herself/himself as being spiritual not only lives with many values, but, according to Taylor (1989:6263), finds that one has to 'rank' that which is acknowledged as 'goods'. Ranking has the effect that some values are regarded as more important than others, with some even being regarded as 'of supreme importance'. That moment in life when a commitment to that which is considered to be 'a highest good' responds to a 'yes/no question' with regard to what is 'utterly decisive for what I am as a person'. Such a decision amounts to a commitment. A strong commitment becomes 'higherorder goods', goods that are 'hypergoods'. Taylor refers to them as follows: 'goods which not only are incomparably more important than others but provide the standpoint from which [values] must be weighed, judged, decided about' Taylor (1989:63).

For Taylor, the love of God and the search for justice are examples of hypergoods (cf. Taylor 1989:62-63; see also pp 63-73, 78, 81, 85, 88, 89, 98, 100-102, 104-106). Within Taylor's North American context, two aspects constitute the present-day 'ethics of justice', namely the sexual revolution of the 1960s and 1970s, and the issue of political integrity within a context of global pluralism after September 11, 2001. Such ethics takes on an interpersonal character, and in Christian circles it reopens the issue, among others, of biblical hermeneutics, especially the phenomenon of conflicting interpretation. Because of the interpersonal nature of such ethics, the question, 'Why should I be moral?', cannot be answered by a Christian simply by making an appeal to the Bible, since each generation needs to find the answer to this question within its own situation and context.

From a hermeneutical point of view, it is simply not possible to regard every statement in the Bible as relevant for all times. Paul Tillich ([1996] 2007), for example, in his work The irrelevance and relevance of the Christian message, cautions against a socalled 'kerygmatic theology' that comes with a proposition of an intangible 'Word from Above', and which expects believers to submit themselves blindly to the authority of God's Word without taking cognisance of the impact of such an appeal on life in reality. When rigid pronouncements taken from the Bible are harmful to people, the power of such propositional claims are irrelevant, simply because these 'propositional truths' cause harm. In continuity with the Schleiermacher tradition, Tillich prefers a responding-listening and meditative use of the Word to a kerygmatic-propositional one.

If the Bible is read from this stance, with the aim to contemplate, pray, confess and preach old and new stories of faith, as if doing so for the very first time, the exegetical approach would be postliberal. Walter Brueggemann (2005:170-171) explains the 'new characteristics of postliberal exegesis' as follows (my paraphrase and interpretation): Though very much aware of the audience, exegetes will not be guided by their conventions, but will speak to their needs in an imaginative and creative way. Brueggemann refers to this as 'an act of imagination'.

Both exegete and audience approach the text from the framework of their own ideologies. The exegete knows that the text does not have one meaning only that would be true for all times. On the other hand, the text cannot be interpreted so freely that it accommodates all ideologies. On the contrary, in a colonialist context, for example, a postcolonial reading would be ideologycritical. The same goes for gender critique in a male-dominated and/or heterosexist world. Brueggemann refers to this as 'the critique of ideology'. Such a critical reading will also expose the denial of ideology by both exegete and audience. Brueggemann refers to this as 'hidden ideology'.

Exegetes approach the text with all that constitutes their being: their presuppositions, prejudices, histories, experiences, bodyliness. Because of an awareness of oneself and the situation of the audience (which includes those inside and outside institutionalised religion), it is impossible to approach the text in a detached, rational and authoritative way. According to Brueggemann, 'every reader and every reading is to some extent contextual'.

For Brueggemann, this kind of biblical exegesis 'has a practical urgency to it', because for too long damage has been done to people, using the Bible as a means to do so. A postliberal reading creates the awareness that 'life-and-death matters are at stake both for the interpreter and for the community of interpretation'.

This exegesis is not the enterprise of institutional religion alone. It is an open question whether this could be regarded as a matter of an institution at all. At least, 'postliberal exegesis' assumes a dialogue between exegetes and 'theologians' in the public square, such as film directors, poets, novelists and artists (cf. Van Aarde 2008:1213-1234).

\section{WHERE TO FROM HERE?}

Against the background of my appreciation of the dialogue between professional theologians and 'theologians' doing 
theology on the public square, referred to above, I would like to close this article in the spirit of the ongoing debate between 'atheists' and 'theists'. Without endorsing the appraisal of 'panENtheism' by the Observer (Dunkirk, New York) columnist, Daniel O'Rourke, but rather reflecting within the framework of the kind of postsecular posttheism which I have proposed in this presentation, I begin my in/conclusion with remarks from O'Rourke's column on the 'atheism-theism debate'. O'Rourke is a married former Roman Catholic priest who retired from the administration of the State University of New York at Fredonia. He is the author of The Spirit at your back: Spiritual reflections on this and that (O'Rourke 2007) ${ }^{4}$ a book that consists of a collection of his contributions that he has written as columnist for the Observer:

There has been a lot of print, talk and footage recently about atheism. Books such as Richard Dawkins' "The God Delusion" and Jonathan Miller's public television series "A brief history of disbelief"5 are just the tip of the iceberg. The subject is clearly in the public forum ...

The threshold questions ... are: what do atheists deny? What do theists affirm?

Proponents of atheism seem to take as a given an anthropomorphic god, which sees god as a super human patriarch. This god, of course, is almost always male and upstairs somewhere. The Greek Philosopher Xenophanes, however, observed long ago, "If horses had gods, their gods would look like horses." It is not surprising then that humans make their gods sound and look human. Indeed we call them father, son, mother-father, but their projected human likeness doesn't end there. Many churchooers believe in - and therefore atheists deny - a god who gets angry, seeks revenge, punishes his enemies and rewards his friends. Many theists, however, don't believe in such a petty, human-like god.

Some theists have a subtler, more spiritual, more universal idea of the Mystery. God isn't "up there" at all; He/She/It (the pronouns never work) is down here: in nature, in us, in relationships ..

The professional atheists, however, ... focus their arguments against the more commonly acknowledged super human deity. They set up a straw man (a straw god?) and then dismantle "him" with their arguments. Their basic argument goes like this: if god is all-powerful and all loving, how can "he" allow suicide bombers, wars, famine, child-porn and teenage acne? This argument, of course, not only presumes and then denies the simplistic chickensoup-for-the-soul god, but also confuses this god with the problem of evil ...

Although both theists and atheists may disagree, let me say frankly: the existence of God has little to do with religion, evil in the world, the nature of Jesus, immortality, reincarnation or survival after death. Yet professional atheists inevitably pull these sidebars into their arguments. Some believers in the Mystery have no religion. Many theists do not believe in Jesus. Some do not believe in personal immortality.

4.See O'Rourke, D., 2007, The Spirit at your back: Spiritual reflections on this and that, 2nd edn., Caritas Communications, Mequon.

5.Dawkins, R., 2006, The God delusion, Houghton Mifflin Company, Boston. With regard to Jonathan Miller, see Julian Ward (2006:76): 'Last autumn BBC2 broadcast regast seinn in 2004 on BBC4. Jonathan Miler is well known as a ( documentary programmes. A son of Jewish refugees from Lithuania, he first became a doctor and later a theatre director. The programmes show his strong hostility to all forms of religion because of their intolerance, persecutions and resistance to science and modern liberal democratic societies. The programmes advocate an irreligious view of life in which belief in God should have no part.'

6.See Xenophanes 6-5 вCE. Fragmenta (Silli et de natura) fasc. 15. cf. also Stanley Ned Rosenbaum (2002: 68, 68 note 4): 'Our religion then, is anthropocentric as well as anthropomorphic. It mirrors us, and, until astronomers proved otherwise, it literally revolved around us ... If cattle and horses, or lions, had hands, or were able to draw with their feet and produce the works which men do, horses would draw the forms of gods like horses, and cattle like cattle, and they would make the gods' bodies the came 15. phrased geometrically: 'If triangles had a god, he et de Montesquieu, a seventeen and political thinker during the Era of the Enlightenment, comes from his Lettre persanes (1721), translated by C.J. Betts (1973:108): 'It has been very well said that if triangles were to make a god for themselves, they would give him three sides.
Bishop John Robinson, in his ground shaking little book, "Honest to God," called for a moratorium on the god-word. He was perceptive. There is no word in the religious lexicon with so much baggage. Perhaps we should also temporarily place words like theism and atheism on the disabled list. ${ }^{8}$ Bishop John Spong has already made the term "theism" suspect, using it disapprovingly for the human-like god who looms over humanity as accuser, judge and jury. ${ }^{9}$

In a fair world, atheists and theists would dialogue. Instead they argue past each other ... I ... would urge professional atheists to read some modern theology such as Marcus Borg's "The God We Never Knew".10 And I wish both would stop being so dogmatic, righteous, snide and judgmental.

Not all believers think atheists are selfish, self-indulgent and destined for hell. Some theists don't even believe in hell. And not all atheists think they are superior to us benighted believers who need the god crutch to deal with life's harshness. Although to listen to the Brights Movement ${ }^{11}$ you might think so. The Brights Movement embraces a world view free from all supernatural, mystical and divine elements. The word "Brights" by which they proudly describe themselves implies that believers are dimwitted.

Not all theists, however, are unintelligent, unthinking, uncritical conformists. That's an ignorant stereotype. Some of the best minds in history have believed and many astute thinkers today believe in Meister Eckert's "Godhead beyond god", "The Light Within the Quakers", or "the Paul Tillich's Ground of Being". Carl Jung, certainly no dimwit, placed this inscription over the door of his home in Kusnacht, Switzerland: "Vocatus atque non vocatus Deus aderit. Whether invoked or not, God will be present". Amen, Doctor, amen.

Institutional religion cannot remain untouched by this dialogue in the public forum. It simply cannot maintain the status quo in a postsecular world. The logical consequence, however, would not necessarily be that religion must come to an end and be replaced by spirituality. By being religious, we have, in the words of Jacques Derrida, returned ('religare') to the roots of our (Christian) religio (Caputo et al. 2005:33), and it has happened not in a metaphysical-theistic sense 'out there', in another sphere of time and space, but right here in our world (saeculum).

Derrida states many times that since techno-science enlarges the religious realm even in opposing it, the secular culture is a religious culture, without dwelling on the other implications that arise here - that there is no religious culture that is not secular through and through.

(Terada 2007:252)

During the pre-modern mythological age, the Latin word religare, which means to 'bind' or to 'keep in protective custody', was used to denote the experience of being in awe of transcendent forces (Simpson 1966:511), positively experienced as trust and negatively as fear. In the Hebrew Bible, 'fear' (jirāh) implies a

7.Robinson, J.A.T., 1963, Honest to God, Westminster Press, Philadelphia. cf. also Funk, R.W., 1996, Honest to Jesus: Jesus for a new millennium, Harper Collins, San Francisco. Please see earlier comment on this.

8.In this respect, in my opinion, 'religious naturalism', proposed by someone such as Jerome A. Stone (2008), at least, must be considered seriously when we have a dialogue on the nature of 'religious orientation' today.

9.Spong, J.S., 2007, Jesus for the non religious: Recovering the divine at the heart of the human, HarperCollins Publishers, New York. See Spong $(2007: 220-221,224)$.

10.See Borg, M.J., 1997, The God we never knew: Beyond dogmatic religion to a more authentic contemporary faith, HarperSanFrancisco, New York.

11.http://www.the-brights.net. According to the study by Anspach, Coe and Thurlow (2007:101), there are 'four major US-based organizations that are either professed (2007: or (he freedom from religin', namely the American Atheists, the American Humanis organizations were identifoct and Dogpile). These Internet searches revealed the presence of 17 primary national atheist/humanist/free-thought organizations, of which the four selected appeared the most prominent. 
respect for the immanent manifestation of the transcendent God (Koehler \& Baumgartner 1958:400). The Latin for 'trust' is fides (Simpson 1966:62), in Greek it is pistis (Liddel \& Scott 1961:1408), and in Hebrew it is 'āmennā (Koehler \& Baumgartner 1958:62). It is this 'trust' or 'faith' that fills the void which is simply part of being human. Postsecular spirituality still consists of the longing for the divine saturation of 'emptiness'.

This longing is simply part of being spiritual, and the more the void is filled, the more one can share the spiritual gifts with others, especially in our secular age. Being religious today is to de-secularise our world by living in the presence of God as a Spirit-filled person. Such transcendence in everydayness implies living in a (Christian) moral manner.

Postsecular spirituality does not, therefore, have to imply the end of religion, but rather the end of exclusive humanism. Within the framework of Walter Brueggemann's understanding of postliberal engaged hermeneutics, I would still like to model my appreciation of Charles Taylor's notion of the 'ethics of authenticity' - which emphasises the love of God and ethics of justice - on a 'biblical truth', despite the relativising cognition of historical contingency that is so prominent in our secularised modern theology. In this sense, the truism of the apostle Paul, living within a pre-modern mythological theistic contextual world and reflecting on the essence of being-in-Christ and beingin-the-Spirit, still 'has a practical urgency to it' (Brueggemann 2005). Even now, in our posttheistic context, this truism remains as a spiritual quest. Similarly to the charismatic Paul appealing to Christians on issues about spirituality in ancient Corinth (see his chapter on charismata in 1 Cor 12), it continues to be a matter of life and death for us too: 'So faith, hope, love abide, these three; but the greatest of these is love' (1 Cor 13:13; Revised Standard Version).

\section{REFERENCES}

Adams, N., 2006, Habermas and theology, Cambridge University Press, Cambridge.

Anspach, W., Coe, K. \& Thurlow, C., 2007, 'The other closet? Atheists, homosexuals and the lateral appropriation of discursive capital', Critical Discourse Studies 4(1), 95-119.

Ashcroft, B., Griffiths, G. \& Tiffin, H. (eds.), 1995, The postcolonial studies reader, Routledge, London.

Berger, P.L. \& Luckmann, T., 1967, The social construction of reality: A treatise in the sociology of knowledge, Doubleday, New York.

Borg, M.J., 1997, The God we never knew: Beyond dogmatic religion to a more authentic contemporary faith, HarperSanFrancisco, New York.

Browning, D. \& Schüssler Fiorenza, F. (eds.), 1992, Habermas, modernity and public theology, Crossroad, New York.

Brueggemann, W., 2005, 'The re-emergence of Scripture: Postliberalism', in P. Ballard \& S.R. Holmes (eds.), The Bible in pastoral practice: Readings in the place and function of Scripture in the church, pp. 153-173, Eerdmans, Grand Rapids.

Butterfield, H., 1975, The origins of modern science: 1300-1800, Bell and Hyman, London.

Caputo, J.D., Hart, K. \& Sherwood, Y., 2005, 'Epoché and faith: An interview with Jacques Derrida', in Y. Sherwood \& K. Hart (eds.), Derrida and religion, pp. 27-50, Routledge, New York.

Clayton, P., 2003, s.v. 'Theism', 'Deism', 'Monotheism', 'Emergence', Encyclopedia of Science and Religion, Macmillan, New York.

Clinebell, H., 1984, Basic types of pastoral care and counselling: Resources for the ministry, of healing and growth, Abingdon, Nashville.

Dawkins, R., 2006, The God delusion, Houghton Mifflin, Boston.

Donaldson, L.E. (ed.), 1998, Postcolonialism and scriptural reading, Scholars Press, Atlanta.

Drewery, W., Winslade, J. \& Monk, G., 2000, 'Resisting the dominating story: Toward a deeper understanding of narrative therapy', in R.A. Neimeyer \& J.D. Raskin (eds.),
Constructions of disorder: Meaning making frameworks for psychotherapy, pp. 243-263, American Psychological Association, Washington DC.

Forman, R.K.C., 2004, Grassroots spirituality: What it is, why it is here, where it is going, Imprint Academic, Charlottesville.

Funk, R.W., 1996, Honest to Jesus: Jesus for a new millennium, Harper Collins, San Francisco.

Goodman, B., 2008, 'Priest-cosmologist wins \$1.6 million Templeton Prize', New York Times, viewed 24 July 2009, from http:www.nytimes.com/2008/03/13/science/13price. html.

Graham E., 2002, 'Liberal theology and transformative pedagogy: A response to Peter Hodgson', in M.D. Chapman (ed.), The future of liberal theology, pp. 129-138, Ashgate, Aldershot.

Grigg, R., 1985, Symbol and empowerment: Paul Tillich's post-theistic system, Mercer University Press, Macon.

Habermas, J., 1981, 'Modernity versus postmodernity', New German Critique 22, 3-14.

Habermas, J., 2002, in E. Mendieta (ed.), Religion and rationality: Essays on reason, God, and modernity, Polity Press, Cambridge.

Habermas, J. \& Ratzinger, J., 2005, Dialektik der Säkularisierung: Über Vernunft und Religion, Herder, Freiburg.

Hill, J.A., 2008, Ethics in the global village: Moral insights for the post 9-11 USA, Polebridge, Santa Rosa.

Hodgson, P.C., 2007, Liberal theology: A radical vision, Fortress Press, Minneapolis.

Inwood, M., 2000, Heidegger: A very short introduction, Oxford University Press, Oxford.

John Templeton Foundation, 2009, Templeton Prize, viewed 24 July 2009, from www.templeton.org/prizes/the_templeton_ prize/.

Kearney, R., 2001, The God who may be: A hermeneutics of religion, Indiana University Press, Bloomington.

Kearney, R., 2004, On Paul Ricoeur: The owl of Minerva, Ashgate, Burlington.

Koehler, L. \& Baumgartner, W., (eds.), 1958, Lexicon in Veteris Testamenti Libros, Brill, Leiden.

Kopfensteiner, T.R., 1992, 'Historical epistemology and moral progress', Heythrop Journal 33, 45-60.

Kuhn, T.S., [1957] 1979, The Copernican revolution, Harvard University Press, Cambridge.

Leaves, N., 2006, The God problem: Alternatives to fundamentalism, Polebridge, Santa Rosa.

Liddel, H.G. \& Scott, R., 1961, A Greek-English Lexicon, 9th edn., Clarendon Press, Oxford.

Melton, J.v.H., 2001, The rise of the public in Enlightenment Europe, Cambridge University Press, Cambridge.

Miller, R.J., 2003, Born divine: The births of Jesus $\mathcal{E}$ other sons of God, Polebridge, Santa Rosa.

Montesquie, C. De S., [1721] [1901] 1973, The Persian letters, transl. C.J. Betts, Penguin, Harmondsworth.

Moore, S.D., 2000, 'Poscolonialism', in A.K.M. Adam (ed.), Handbook of postmodern Biblical interpretation, pp. 182-188, Chalice Press, St. Louis.

O'Rourke, D., 2007, The Spirit at your back: Spiritual reflections on this and that, 2nd edn., Caritas Communications, Mequon.

O'Rourke, D., 2008, The atheism theism debate, viewed 24 July 2009, from www.danielcorourke.com.

Pambrun, J.R., 2001, 'Hermeneutical theology and narrative', Theoforum 32(3), 273-301.

Philipse, H., 2004, Atheistisch manifest/De onredelijkheid van religie, Bert Bakker Uitgeverij, Amsterdam.

Philipse, H., 2007, Wetenschap versus godsdienst: Een hoorcollege over grote conflicten van Copernicus tot Dawkins, 8 CDs, Home Academy Publishers, The Hague.

Philipse, H., 2008, 'Godsgeloof in het tijdperk van wetenschap: Een epistemologisch drama', Nederlands Theologisch Tijdschrift 62(3), 177-195.

Ricoeur, P., 1984-5, Time and narrative, Chigago University Press, Chicago. 
Ricoeur, P., [1989] 1995, 'Pastoral praxeology, hermeneutics, and identity', in P. Ricoeur, 1995, Figuring the sacred: Religion, narrative and imagination, transl. D. Pellauer, ed. by M.I. Wallace, pp. 303-315, Fortress Press, Minneapolis.

Robinson, J.A.T., 1963, Honest to God, Westminster Press, Philadelphia.

Rosenbaum, S.N., 2002, Understanding Biblical Israel: A reexamination of the origins of monotheism, Mercer University Press, Macon.

Schrag, C.O., 1997, The self after postmodernity, Yale University Press, New Haven.

Scott, B.B. (ed.), 2008, Resurrection of Jesus: A sourcebook, Polebridge, Santa Rosa.

Selesnick, S.T., 1966, Carl Gustav Jung 1875-1961: Contributions to psychoanalysis, Basic Books, New York.

Simpson, D.P., [1959] 1966, Cassell's new Latin dictionary, 4th edn., Jarrold \& Sons, Norwich.

Sobel, S.J.H., 2004, Logic and theism: Arguments for and against beliefs in God, Cambridge University Press, Cambridge.

Spong, J.S., 2007, Jesus for the non religious: Recovering the divine at the heart of the human, HarperCollins, New York.

Stone, J.A., 2008, Religious naturalism today: The rebirth of a forgotten alternative, State University of New York, Albany.

Swinburne, R., [1977] 1993, The coherence of theism, rev edn., Clarendon Press, Oxford.

Taussig, H., 2006, A new spiritual home: Progressive Christianity at the grass roots, Polebridge, Santa Rosa.

Taussig, H., 2008, 'Disparate presence', in C.W. Hedrick (ed.), When faith meets reason: Religion scholars reflect on their spiritual journeys, pp. 149-160, Polebridge, Santa Rosa.

Taylor, C., 1989, Sources of the Self: The making of the modern identity, Harvard University Press, Cambridge.

Taylor, C., 1991, The ethics of authenticity, Harvard University Press, Cambridge.
Taylor, C., 2007, A secular age, The Belknap Press of Harvard University Press, Cambridge.

Terada, R., 2007, 'Scruples, or faith in Derrida', in I. Balfour (ed.) Late Derrida, pp. 237-264, Duke University Press, Durham.

The Brights, 2009, Illuminating and elevating the naturalistic worldview, viewed 24 July 2009, from http://www.thebrights.net.

Tillich, P., [1996] 2007, in D. Foster (ed.), The irrelevance and relevance of the Christian message, Wipf \& Stock, Eugene.

Van Aarde, A.G., 1994, 'The epistemic status of the New Testament and the emancipatory living of the historical Jesus in engaged hermeneutics', Neotestamentica 28(2), 575596.

Van Aarde, A.G., 2008, 'What is "theology" in "public theology" and what is "public" about "public theology"?', HTS Teologiese Studies/Theological Studies 64(3), 1213-1234.

Van Huyssteen, J.W., 1999, The shaping of rationality: Toward interdisciplinarity in theology and science, Eerdmans, Grand Rapids.

Vos, A., 2008, 'De onbetaalde rekening van de moderne theologie', Theologisch Debat 5, 29-35.

Wallace, M.I., [1990] 1995, The second naiveté: Barth, Ricoeur, and the New Yale Theology, Mercer University Press, Macon.

Ward, J., 2006, 'The challenge of aggressive atheism: The author responds to Jonathan Miller's promotion of atheism in his recent television series', Evangel 24(3), 76-85.

Young, R.C., 1996, Torn halves: Political conflict in literary and cultural theory, Manchester University Press, Manchester.

Young, R.C., 2001, Postcolonialism: An historical introduction, Blackwell, Oxford.

Xenophanes, 6-5 BCE, Fragmenta (Silli et de natura), in E. Diehl (ed.), 1949, Anthologia lyrica Graeca, 3rd edn., fasc. 1, pp. 6874, Teubner, Leipzig. 